\title{
RESIDENTS' PERCEPTION TOWARDS GEOHERITAGE CONSERVATION AND TOURISM DEVELOPMENT: EVIDENCE FROM JODHPUR, INDIA
}

\author{
Sandeep Kumar DEY* \\ Tomas Bata University in Zlin, Faculty of Management and Economics, Zlin, Czech Republic, e-mail: dey@utb.cz \\ Reshma Sandeep Kumar DEY \\ Central University of Kerala, Department of Tourism Studies, Kerala, India, e-mail: reshmasdey@gmail.com
}

Zuzana TUCKOVA

Tomas Bata University in Zlin, Faculty of Management and Economics, Zlin, Czech Republic, e-mail: tuckova@utb.cz

\begin{abstract}
Citation: Dey, S.K., Dey, R.S.K., \& Tučková, Z. (2021). RESIDENTS' PERCEPTION TOWARDS GEOHERITAGE CONSERVATION AND TOURISM DEVELOPMENT: EVIDENCE FROM JODHPUR, INDIA. GeoJournal of Tourism and Geosites, 38(4), 1057-1068. https://doi.org/10.30892/gtg.38410-744
\end{abstract}

\begin{abstract}
The Mehrangarh Fort in Jodhpur, India, located at the height of 150 meters above the surrounding sandy plains, is one of the city's most prominent monuments built over the Jodhpur group-Malani-Igneous Suite. The old city, which boasts numerous blue-painted houses, lies adjacent to the Mehrangarh Fort. The residents of the old city play a significant role in keeping the geoheritage and cultural heritage intact. The study investigates the moderating role of residents' Perception towards support for Geoheritage Tourism and Conservation in and around Mehrangarh Fort. A combination of Weber's theory of substantive and formal rationality (WTSFR) and Social Exchange Theory (SET) is used to investigate and infer the interposing and moderating role of residents' perception on the relationship between influencing factors and support for geo-heritage conservation. A PLS evaluation of the SEM reveals a substantial capacity of the residents' perception to predict support for conservation and tourism development.
\end{abstract}

Key words: geoheritage, tourism development, social exchange theory, residents' perception

\section{INTRODUCTION}

The area of this study is a geo-site notified by the Geological Survey of India as a National Geological Monument known as the Jodhpur Group-Malani Igneous Suite Contact. This geological structure marks the final period of igneous activity on the Indian subcontinent during the Precambrian period. The term was changed numerous times throughout the years, including Malani Beds (Blanford, 1877), Malani Volcano Series (La Touche, 1902), Malani System (Coulson, 1933), The Malani Granite and Volcanic Suite (Pascoe, 1959), and ultimately Malani Igneous Suite (Pareek, 1981). The Mehrangarh Fort, located at the height of 150 meters above the surrounding sandy plains, one of the city's most prominent monuments, is built over this group of rocks (Kaur, 2020).

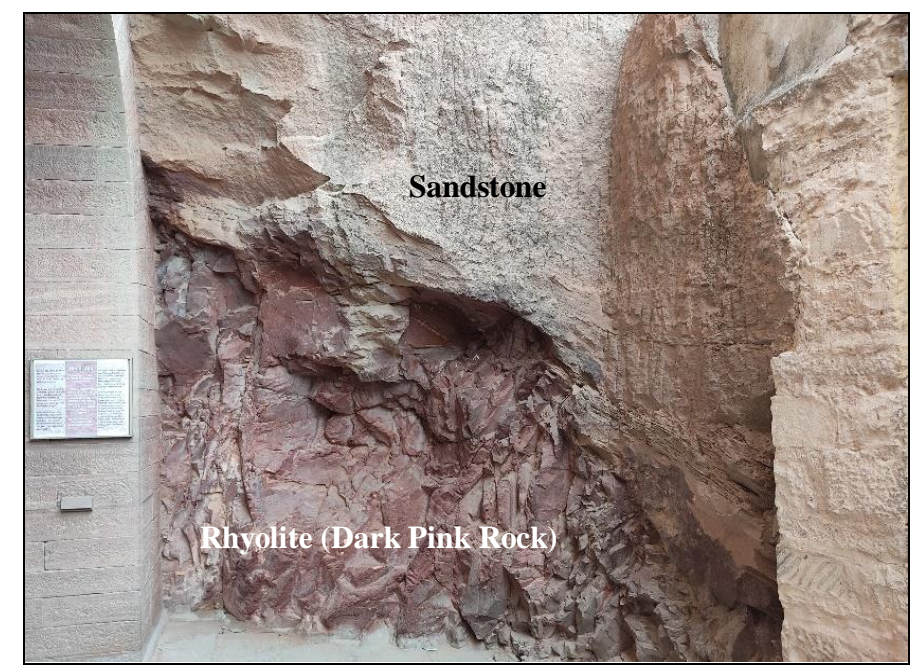

Figure 1. Contact between Malani Volcanics and Jodhpur Sandstone with 'Unconformity', rock structure exposed near the entrance of Mehrangarh Fort (Source: Authors' own)

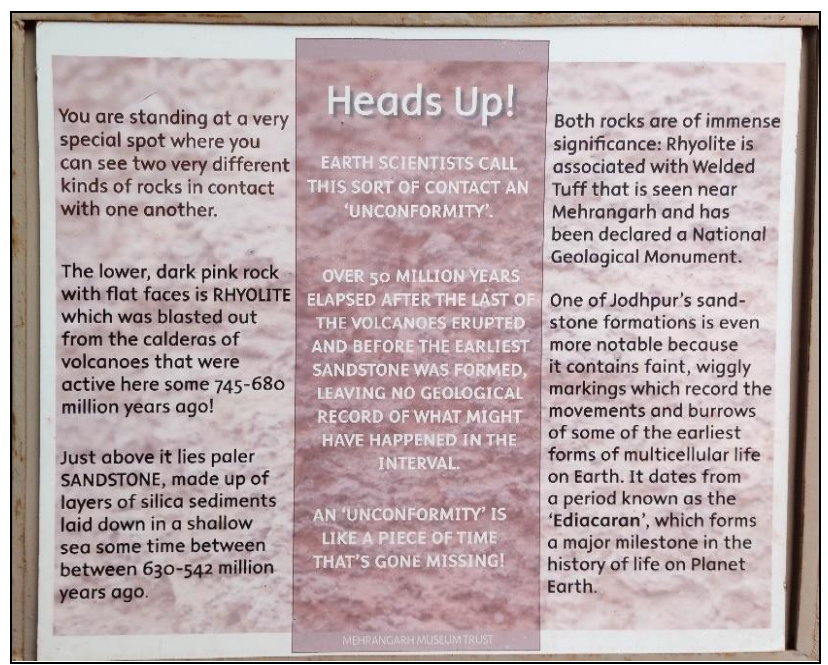

Figure 2. The information provided near the 'unconformity' exposed close to the entrance of Mehrangarh Fort Palace (Source: Authors' own)

\footnotetext{
${ }^{*}$ Corresponding author
} 
This is also an important geological site, with a robust erosional contact between the Malani Volcanics and the Jodhpur Sandstone atop it. Geologists call this phenomenon an "unconformity" as there is no record of continuous sedimentation in the particular region. The feature contains a non-depositional surface separating two rock masses from two different ages. (Pareek, 1981) noted three phases of Magmatism in Malani-Igneus Suite; significant felsic and minor mafic flows (Extrusive phase), granitic plutons (Intrusive phase), and Felsic and mafic dike swarms (Dike phase). Malani Rhyolites and associated lavas, tuff, welded tuff, and mafics of MIS have formed $600 \pm 70$ Ma. After a period of unconformity, during the Ediacaran age (635-542 Ma), the Malani-Igneus-Suite was overlaid by a deposit of Jodhpur Sandstone which belongs to the Marwar Supergroup (Kaur et al., 2020; Pandey and Bahadur, 2009).

This unconformity is exposed at Mehrangarh Fort, near the entrance (Figure 1). Malani Rhyolites, in Pink, maroon, brown, purple, grey, and green colours are separated by tuff, welded tuff, and pyroclastic rocks. The columnar joints that have been created the range in size from rectangular to hexagonal, with some reaching a length of 30 meters or more. Porphyritic rhyolite with a rich purple colour covers it (Pareek, 1981). While driving out of town, the welded tuff outcrop is about 100 meters on the right side of the road, just before the Mehrangarh Fort and also visibe below the fortified structure (shown in Figures 3, 4, 5 and 6). The old city in Jodhpur, which boasts numerous blue-painted houses, is encircled by a wall with many gates and surrounds the Mehrangarh Fort (Figure 7). However, during the last few decades, the city has grown significantly outside of the wall.
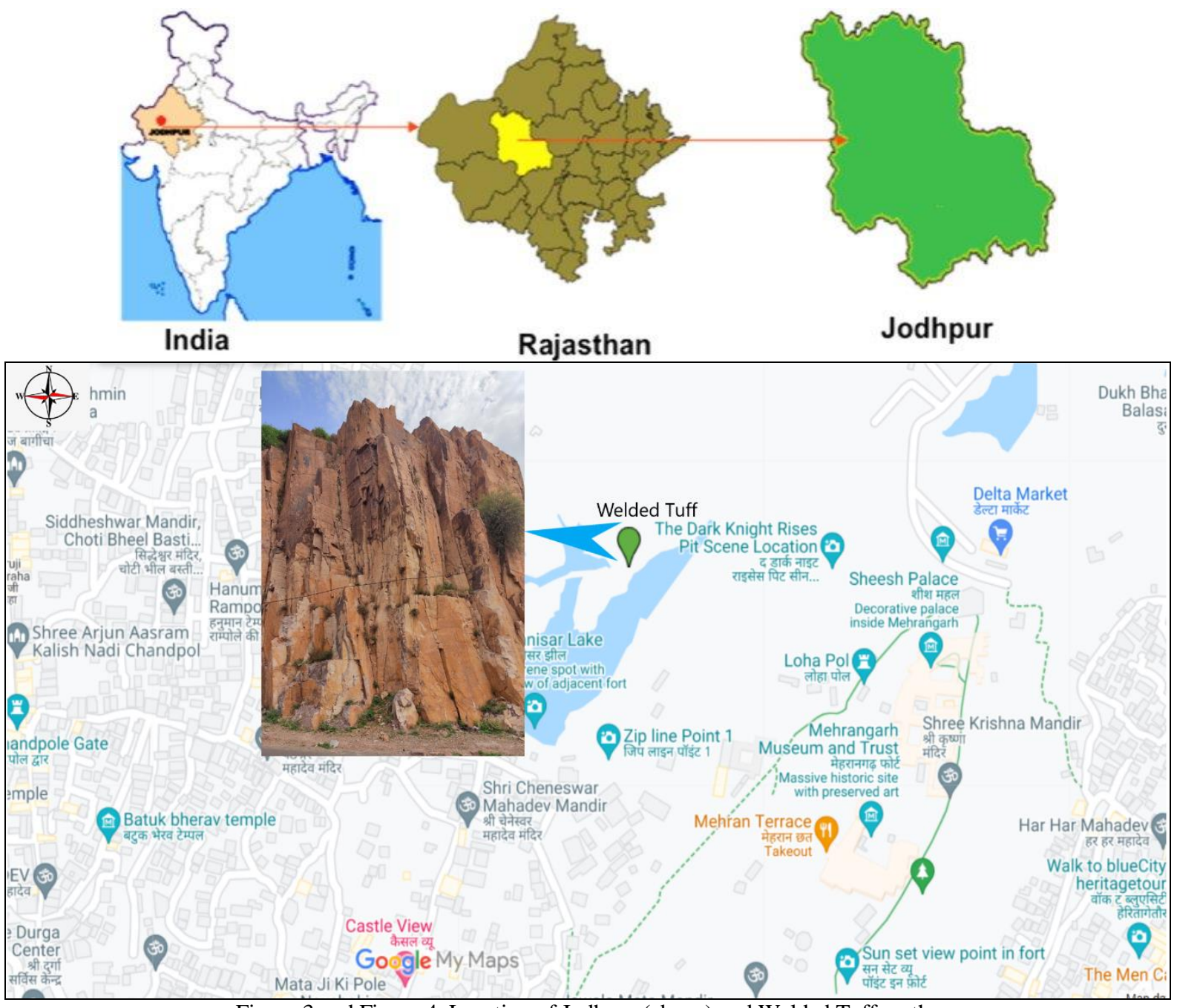

Figure 3 and Figure 4. Location of Jodhpur (above) and Welded Tuff on the way to Mehrangarh Fort (below) (Source: Lama and Rathore, 2018; Maps, 2012)

A study towards understanding residents' psychology towards geo-heritage conservation and tourism development is a call to action (Gannon et al., 2020). This study is particularly interested in answering two pertinent research queries viz; $a$ ) what are the antecedents of residents' support towards conservation of the geo-site and tourism development and $b$ ) what is the moderating effect of residents' perception towards geo-heritage conservation.

In academic literature, various terminologies have been used to study the concept of "residents' perception" in the context of heritage conservation; the nomenclatures used to define the construct of "perceptions" include terms like "attitudes" and "reactions" (Andereck and Vogt, 2000; Byrd et al., 2009; Da Silva Lopes et al., 2019; Davis et al., 1988; Garau-Vadell et al., 2013; García et al., 1995; Jurowski et al., 1997b). Irrespective of the various terminologies used to identify and investigate the emotions of residents towards heritage conservation and tourism development, the significant 
parameters that are taken into cognisance are based upon the direct, indirect, and undetermined effects that tourism and conservation efforts have on the local inhabitants (Sharpley, 2014). Recent researches in the field of residents' perception about tourism development purport the fact that natives are usually supportive of any initiative that leads to more arrival of tourists in their regions when they positively discern the impacts in the long run (Látková and Vogt, 2012; Nicholas et al., 2009; Nunkoo and Ramkissoon, 2010; Rasoolimanesh et al., 2017; Sharpley, 2014).

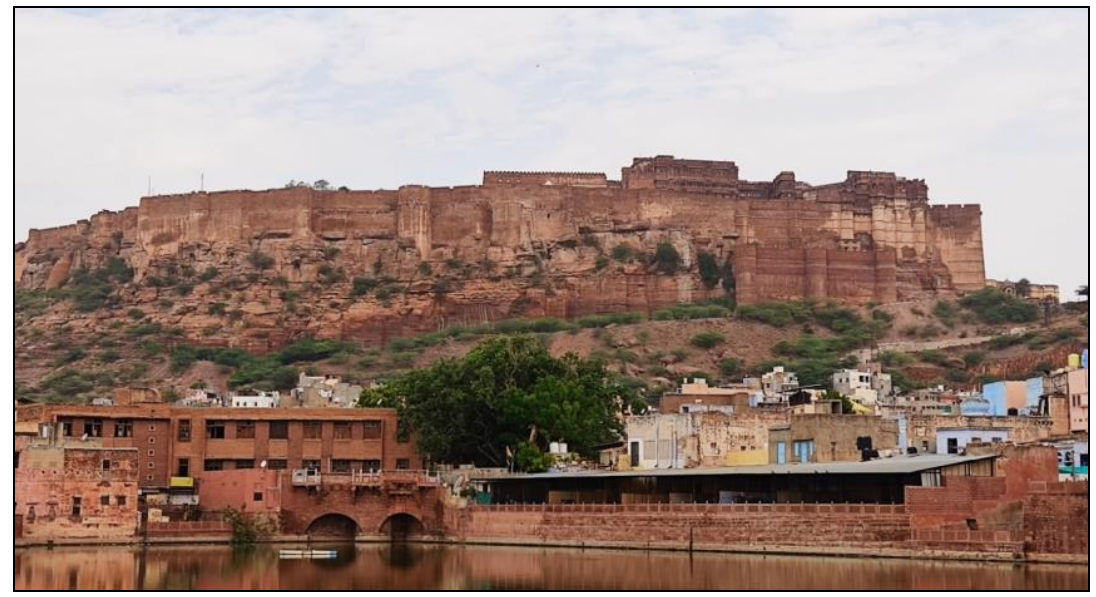

Figure 5. The Mehrangarh Fort build in Jodhpur Sandstone located over the Jodhpur group of Malani-Igneus Suite (Source: Authors' own)

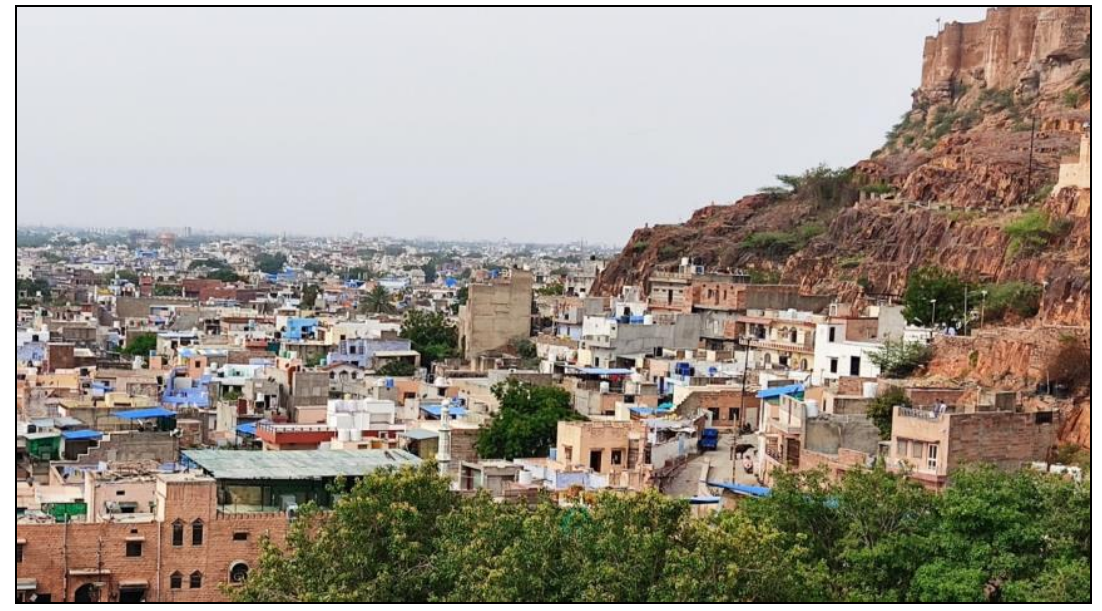

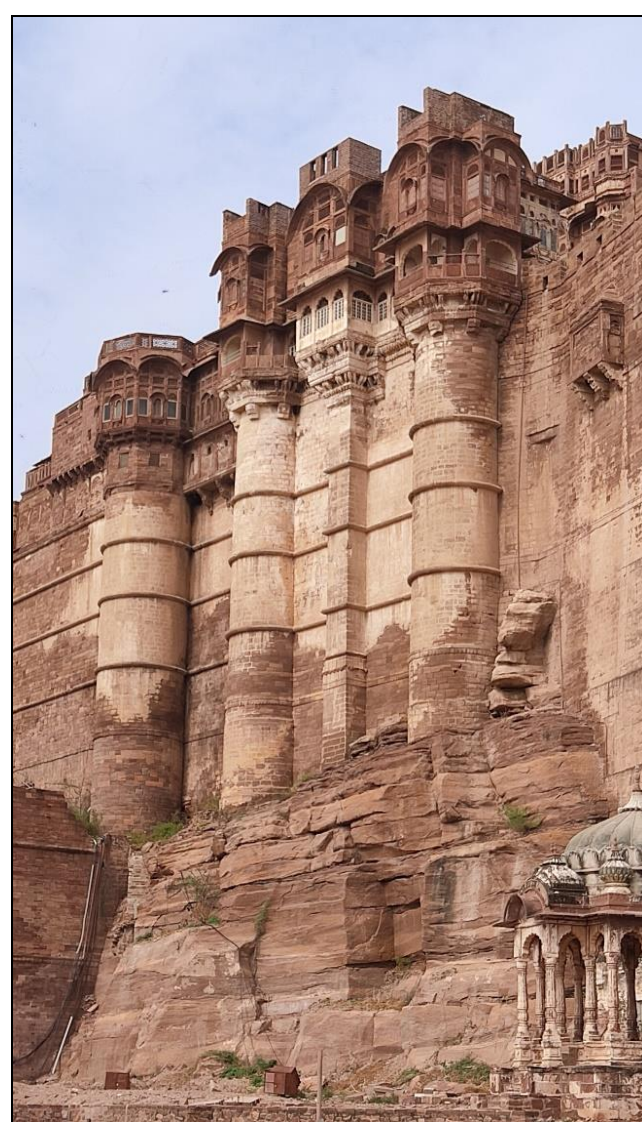

Figure 6. The welded tuff below the fortified structure of Mehrangarh Fort Palace (Source: Authors' own)

Figure 7. The local community staying close to Mehrangarh Fort (Source: Authors' own)

Tourism as an economic activity impacts the local communities by incrementing labour and entrepreneur prospects, advancing infrastructure, raising living standards, improving leisure and recreation capabilities, and facilitates the preservation of indigenous culture (Andereck and Vogt, 2000; Deery et al., 2012; Hwang et al., 2012). On the other hand, negative influence from the incoming tourists cannot be ignored, with prominence given to accruing costs of living and property rates, urban congestion and rise in organised crimes (Deery et al., 2012; Hwang et al., 2012; Látková and Vogt, 2012). Taking cognisance of this discrepancy, previous researches have focussed on factors like the impact of community attachment (Gursoy et al., 2002; Látková and Vogt, 2012) community involvement ((Nicholas et al., 2009); (Rasoolimanesh et al., 2017), attitudes towards the environment (Gursoy et al., 2002; Nicholas et al., 2009), cultural and ethological attributes (Rasoolimanesh et al., 2017), economic benefits (Jaafar et al., 2015; Ko and Stewart, 2002) on resident's attitude towards the impact(s) of tourism development in their locals.

Furthermore, ( $\mathrm{Ng}$ and Feng, 2020) have highlighted the effects of such factors on geoheritage conservation in the purview of residents. Theoretically, exploring the hosts' perspective's role can increase the available knowledge and litmus test the incorporation of residents' perception in previous literature, which may guide studies to gauge such relationships in the future. Pragmatically, this study aims to supplement the efforts of destination planners, managers and other operatives to optimally manage and administer the heritage tourism inventory while stimulating the host's perception towards their communities and channelising the same towards conservation efforts.

\section{THEORETICAL LENSES}

Scrutiny of literature reveal that multiple theories have been expedited to explain the role of influencing factors in moulding hosts' perception towards geoheritage conservation. Authors (Nicholas et al., 2009; Rasoolimanesh et al., 2017) expedited the role of stakeholder theory while (Rasoolimanesh et al., 2019) used Weber's theory of formal and substantive rationality to approach the notion of residents' perceptions. However, (Gursoy et al., 2002; Jurowski et al., 1997b; Ko and Stewart, 2002; Látková and Vogt, 2012; Rasoolimanesh et al., 2015; Sharpley, 2014) observe domination of the social 
exchange theory (SET) in the discussion. Andereck et al., 2005; Jurowski et al., 1997b; Wang and Pfister, 2008 observe that SET explains why residents are encouraged to support heritage conservation when they sense the positive impacts preponderate the negative ones. On the other hand (Rasoolimanesh and Seyfi, 2020) note that SET may suffer from certain lacunae, as it may only comprehend the effects of positive and negative perceptions towards heritage conservation; furthermore, investigations by (Andereck et al., 2005; Boley et al., 2014; Sharpley, 2014) have highlighted the weakness of SET to clarify the factors influencing the perception of residents. (Cropanzano et al., 2017) have been critical of the SET in its capacity to capture behavioural antecedents and imprecise behavioural predictions.

Andereck et al., 2005; Boley et al., 2014; Rasoolimanesh, et al., 2017 have considered the adoption of Weber's theory of substantive and formal rationality (WTSFR) propounded by (Weber, 1978) to offset the epistemological deficiencies laid above and simultaneously develop scientific inquiries to determine factors affecting residents' perception towards conservation. The merit associated with WTSFR is that it aims to describe actions and perceptions based on two rationality types: substantive and formal (Boley et al., 2014). Substantive rationality concerns impressions, value systems, thoughts and ethical motives (Boley et al., 2007). Ward and Berno, 2011 argue that there exists a dissimilarity among hosts and visitors from the point of view of demography which subsequently moulds the hosts' deportment and attitudes towards tourism development. However, the SET is not fully cognised of this differential (Ward and Berno, 2011b). This is a significant consideration that motivated researchers to imbibe facets of Weber's Theory of Substantive and Formal Rationality to study the interactions among hosts and natives in tourism development and conservation. A few critical works of literature includes (Boley et al., 2014; Ranasinghe and Pradeepamali, 2019; Rasoolimanesh et al., 2017). Therefore, to study, capture and predict host behaviour in the context of conservation of a geoheritage and tourism development, this study deploys substantive factors from the WTSR like the quality of life (Uysal et al., 2016) and resident's utilisation of resources (Allen et al., 1993) and support for conservation from the SET (Ng and Feng, 2020). After a thorough literature review, it is revealed that the moderator of choice residents' perception is a novel interaction under investigation to understand the effectiveness of attitude of hosts towards not only developing a tourism product and conserving a geological feature.

Furthermore, the interaction effect is a call to action by (Boğan et al., 2020), who studied the dynamics of this construct in the context of hotel social responsibility. The above premises provide the authors with enough ground to amalgamate both the WTSFR and SET. The study aims to provide pragmatic solutions to managing and promoting a geosite and develop a sustainable tourism model by considering the local community's central role. The study will be executed by investigating and inferring upon the hedonic, perceptive, trade-off relationships with support for conservation endeavours and the moderating role of residents' perception between the influencing factors and support conservation. The study aims to capture, process and predict residents' support for preserving geo-heritage sites and tourism potential.

\section{LITERATURE REVIEW}

\section{Theoretical Framework and Constructs}

The study finds its inspiration and pertinent gap(s) from (Gannon et al., 2020), wherein the investigation recommends that future studies should examine novel independent variables, namely; place image, safety and security, personality, resident's utilisation of heritage and tourism resources, well-being and quality of life, the current study aims to gauge the relationship between above factors and support for geo-heritage conservation

(a) Place Image

Kotler et al., 1993 defined the concept of place image as "the sum of beliefs, principles, and impressions that individuals have towards a certain place". Shields, 2013 through their book titled "Places on the margin: Alternative geographies of modernity" describe "the various discrete meanings associated with real places or regions regardless of their character in reality". Authors like (Ajayi and Tichaawa, 2020; Hankinson, 2004; Stachow and Hart, 2010; Warnaby, 2009) have indicated that individuals may develop distinctive attitudes towards a particular place based on experiences and associations they have from it; furthermore, these attitudes translate into a stereotype when they become widely putative (Boisen et al., 2011). Individual's discernment of physical places is ambiguous and is non-represent of reality Anholt, 2010 and Dinnie, 2011. Stylidis et al., 2014b) deployed a scale and proposed that residents' place image influences their perception of tourism and subsequently mould their support for tourism development. Still, the outcomes outline the need for a more resident-centred measuring vehicle to capture tourism impacts.

\section{H1: Place image has a significant effect on the support for geoheritage conservation}

(b) Safety and Security

Safety and security can be defined as the state of knowing that any agent will induce no harmful effects under specific conditions. In tourism academia, a study by (Chiciudean et al., 2019) has used resident's feelings of safety and security to determine the critical factors for sustainable rural development. In another study, researchers (Imbeah et al., 2020; Wang et al., 2010) reveals that female residents of the Chinese city of Shandong reported reluctance to embrace tourism due to safety and security concerns, which makes the construct even more vital for academic scrutiny, (Konstantaki and Wickens, 2010) corroborate the same through their findings among London residents which showed lack of confidence about the security arrangements made during the 2012 London Olympic Games. (Rasoolimanesh et al., 2017) conceptualised the measure of "community gain" wherein one of the critical parameters is residents' perception towards community safety and security; their study aims to gauge the collective perception of the inscription of George Town in coastal Malaysia as a WHS. 
H2: Safety and Security have a significant effect on support for geoheritage conservation

(c) Resident's Utilisation of Resources

Drumm and Bank, 2005 have described a community in the context of protected areas like World Heritage Sites as "a heterogeneous group who share residence in the same geographic area and access a set of local natural resources", residents in and around the vicinities of World Heritage Sites have increasing access to the opportunity to make decisions about their consumption of resources and livelihood infrastructure (Cochrane and Tapper, 2006). Furthermore, the stakeholder theory and critically analysed the interaction between locals and wildlife-based tourism developments in Zimbabwe, wherein it was observed that locals are to be considered the traditional users of resources in the natural site. Jurowski et al., 1997a has utilised tourism resource utilisation as an exogenous variable to determine residents' support for tourism in a mountain tourism zone in Virginia (US). Jurowski and Gursoy, 2004 observed a direct inverse relationship between the utilisation of tourism resource base and the cultural costs. Jurowski and Gursoy, 2004 differentiated their sample into 3 sub-samples based on a group's physical proximity to a World Heritage Site; the prediction indicated varying sentiments towards resource consumption among the groups. Imbeah et al., 2020 have argued that while residents are aware that resource duplicity exists in the use of resources among natives and tourists, further research should explore how this affects support for conservation.

\section{H3: Residents utilisation of resources have a significant impact on the support for conservation efforts}

(d) Resident's Well Being

In recent decades, increasing emphasis has been paid to the role of tourism planners in attempting to contribute to the well-being of local inhabitants by reducing the potential costs of tourism development, and research provides that residents have a positive lineation towards tourism development if they know about their well-being which happens to be at the heart of all the growth (Lopes et al., 2019). Although a study by (Wu et al., 2019) have stated the effect of subjective well-being (SWB) in the context of tourist perception at geoheritage tourism sites, no such studies have kindled on the topic of residents well-being. Therefore, the current study aims to empirically test the relationship between well being of the resident and support for geoheritage conservation as (Park et al., 2020) believe that residents are significantly more inclined towards support for a protected area when they sense that the action of supporting conservation will offset the ills effects of visitor movements in their local commune which is again a disposition of the Weber's Two Factor Rationality.

\section{H4: Resident's well-being has an impact on the support for conservation}

(e) Quality of Life

Andereck and Nyaupane, 2011 developed the TQOL or the Tourism Quality of Life (QoL) to understand the resident's side of tourism impacts to their overall living standards, which, among other things, consist of factors like air and water quality, preservation of a way of life, state of public transportation, among others. The interdependence between tourism development and quality of life has attracted the interest of researchers since the last decade (Han et al., 2019; Kim et al., 2013; Ko and Stewart, 2002; Uysal et al., 2016) also utilised this item. Its relationship with the residents' support for geoheritage conservation has been discerned by (Syarafina and Misni, 2016), who had observed a significant and positive effect of QoL on ensuring the sustainability of a geopark in Indonesia. Hence, it would be interesting to investigate the same in the context of Jodhpur.

\section{H5: Quality of life for residents have a significant effect on support for conservatory actions}

(f) Support for Conservation

Megeirhi et al., 2020 utilised the VBN (value-belief-norm) to understand local residents of Carthage intentions to support sustainable cultural heritage tourism development, wherein it was observed that psychological precedents are responsible for moulding residents attitudes towards tourism development, in another study by (Ng and Feng, 2020) recorded that positive attitude among the locals dwelling around a UNESCO world heritage site supported tourism propagation, while negative attitude portrays a lack of support. An interdisciplinary approach towards understanding residents' support for conservation efforts of a national park in Botswana reveals that various demographic factors like literacy, employment status and proximity to the site play a pivotal role.

(g) Residents Perception

Zheng et al., 2019 deployed the cognitive appraisal theory and identified the causes of residents' emotional responses to developing a performing arts facility for tourist consumption. The study elicited specific attributes of residents' perceptions like happiness, love, and gratefulness but was negatively related to sadness and anger. Additonally, the study highlighted the fact that positive effects had more impact on touristic performing arts development than negative. Monterrubio et al., 2020 used a negativity biased approach to gauge the emotions and attitudes of local residents towards the result of an airport. It was observed that perceived negative image outweighs all positive outlooks, a contrast from the former study. The current study is built upon antecedents from (Jaafar et al., 2015) who identified that residents' perception towards the conservation of a world heritage site in Malaysia was an important factor in explaining the overall propensity of young people towards promoting and sustaining World Heritage Sites in their locality. Furthermore, Rastegar concluded that resident attitudes towards tourist development within and around protected areas play a fundamental role in deciding the future trajectory for the destination in terms of policy and sustainable governance. Therefore, the authors contemplate examining the moderating role of local perception towards geoheritage and tourism development in the current study as the authors adopt a post-positivist approach to study the transactions between tourism activities and the local populace (Henderson, 2011; Khayati and Zouaoui, 2013). In the post-positivist 
paradigm, the researchers are interested to examine and predict social phenomenons (like residents' perception) against the background of a context (geoheritage) (Henderson, 2011b).

H6: Residents' perception moderates the relationship between safety and security and residents' support for conservation

H7: Residents' perception moderates the relationship between resident's utilisation of resources and residents' support for conservation

H8: Resident's perception has a significant influence on well-being, which affects residents support for conservation

H9: Resident's perception has a significant influence on place image, which affects residents support for conservation

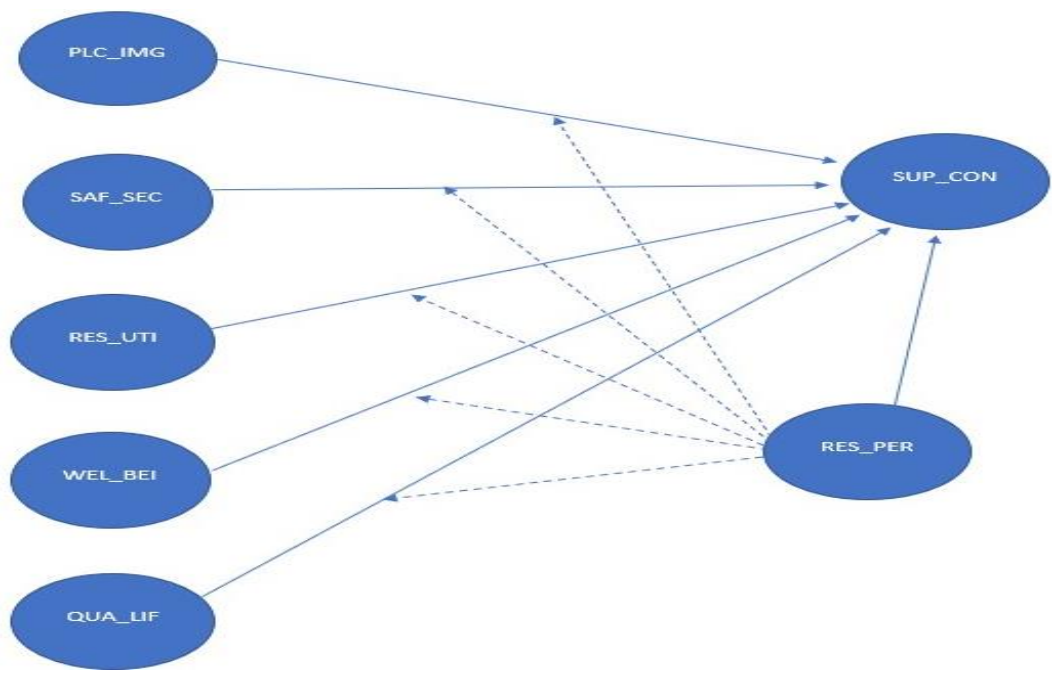

Table 1. Demographical Statistics of the Study

Figure 8. Conceptual Framework Developed by the Authors

\begin{tabular}{|c|c|c|c|}
\hline Items & Category & Frequency & Ratio(\%) \\
\hline \multirow{3}{*}{ Gender } & Female & 46 & 45.5 \\
\cline { 2 - 4 } & Male & 54 & 53.5 \\
\cline { 2 - 4 } Age & & & \\
\hline & $18-30$ & 96 & 95.05 \\
\cline { 2 - 4 } & $31-40$ & 5 & 4.95 \\
\hline \multirow{3}{*}{ Education } & $\begin{array}{c}\text { Master or } \\
\text { higher }\end{array}$ & 37 & 64.4 \\
\cline { 2 - 4 } & Bachelor & 64 & 35.6 \\
\hline & & & \\
\hline \multirow{5}{*}{ Occupation } & Employed & 11 & 10.9 \\
\cline { 2 - 4 } & Self-employed & 6 & 5.9 \\
\cline { 2 - 4 } & Student & 79 & 78.2 \\
\cline { 2 - 4 } & Unemployed & 5 & 5.0 \\
\hline
\end{tabular}

\section{RESEARCH METHODOLOGY}

1. Sampling and data collection procedure

This study was conducted based on the conceptual framework presented in Figure 8. Randomised sampling methodology was utilised to give equal opportunity to all participants to have their responses scrutinised. Residents of Old city, Jodhpur (men, women and others) aged betweenz 18-60 participated in the data collection drive. Due to the ongoing COVID-19 pandemic, an online response collection campaign was conducted between January 2021 and March 2021. A sample size of 200 was estimated in conjunction with the ten times rule promulgated by (Sarstedt et al., 2014).

\section{Scale and Questionnaire Design}

Table 2. Measurement scale developed by the authors

\begin{tabular}{|c|c|c|c|}
\hline Symbol Assigned & Construct & Operationalisation & Scale Adopted \\
\hline PLC_IMG & Place Image & $\begin{array}{l}\text { 1. Effective local government } \\
\text { 2. Good job opportunities } \\
\text { 3. Interesting historic sites } \\
\text { 4. Clean }\end{array}$ & $\begin{array}{l}\text { (Stachow and } \\
\text { Hart, 2010); } \\
\text { (Warnaby, 2009) }\end{array}$ \\
\hline SAF_SEC & Safety Security & $\begin{array}{l}\text { 5. There is enough civil defense infrastructure available } \\
\text { 6. Crimes against women and children are significantly low } \\
\text { 7. Cases of vandalism are rare } \\
\text { 8. This is a safe place to live } \\
\end{array}$ & $\begin{array}{l}\text { (Muresan et al., } \\
\text { 2019) } \\
\text { (Konstantaki and } \\
\text { Wickens, 2010) } \\
\end{array}$ \\
\hline RESI_UTIL & $\begin{array}{c}\text { Residents } \\
\text { Utilisation of } \\
\text { Tourism Resources }\end{array}$ & $\begin{array}{l}\text { 9. There is access to public services for all residents } \\
\text { 10. Locals make use of hotels and restaurants frequented by tourists } \\
\text { 11. Locals have access to infrastructure like roads, accommodations used by tourists }\end{array}$ & $\begin{array}{l}\text { (Jurowski and } \\
\text { Gursoy, 2004), } \\
\text { (Manwa, 2003) }\end{array}$ \\
\hline WEL_BEIN & Well Being & $\begin{array}{l}\text { 12. I feel my basic necessities are being met } \\
\text { 13. There are enough facilities to relax and rejuvenate in the city } \\
\text { 14. I find it wholesome living in this city }\end{array}$ & $\begin{array}{l}\text { (Lopes et al., } \\
\text { 2019) }\end{array}$ \\
\hline QOL & Quality of Life & $\begin{array}{l}\text { 15. There are places for passive and participative recreational activities } \\
\text { 16. I have the opportunity to socialise with my neighbours. } \\
\text { 17. I can fully express my creativity and talent in the city-sphere }\end{array}$ & $\begin{array}{l}\text { (Uysal et al., 2016) } \\
\text { (Burckhardt and } \\
\text { Anderson, 2003) } \\
\end{array}$ \\
\hline RES_PER & $\begin{array}{l}\text { Resident's } \\
\text { perception }\end{array}$ & $\begin{array}{l}\text { 18. The destination implements environmentally responsible actions } \\
\text { 19. The destination implements special programs to minimise any negative } \\
\text { impact on the environment } \\
\text { 20. The destination contributes to the positive development of society }\end{array}$ & $\begin{array}{l}\text { (Zheng et al., } \\
\text { 2020) (Su et al., } \\
\text { 2019) }\end{array}$ \\
\hline SUPP_CON & $\begin{array}{l}\text { Support for } \\
\text { conservation }\end{array}$ & $\begin{array}{l}\text { 21. I engage in local conservation activities } \\
\text { 22. I support sustainable development of the tourism industry around the geo-site } \\
\text { 23. I will support future conservation efforts } \\
\text { 24. I am involved in the well-being of the site }\end{array}$ & $\begin{array}{l}\text { (Megeirhi et al., } \\
\text { 2020) (Ng and } \\
\text { Feng, 2020) }\end{array}$ \\
\hline
\end{tabular}




\section{Data analysis}

Partial Least Square Regression was used to capture and predict residents' behaviour based on the moderating effect of Resident Perception on Support for Conservation Activities. The SMART-PLS Package by (Hair et al., 2017) was utilised for the analysis. Test for Common Method Bias was conducted through the Factor Analysis Module of SPSS by IBM, and the dataset achieved $<50 \%$, which is admissible under Harman's Single Factor Test for measurement bias. The rationale behind selecting the PLS-Structuring Equation Modeling was based on the significant number of investigations involving residents' attitudes and support for conservation and tourism development which used the PLS-SEM method (Gursoy and Rutherford, 2004; Jurowski et al., 1997a; Liang and Hui, 2016a; Stylidis et al., 2014a; Williams and Lawson, 2001). Additionally, statistical treatments by the PLS-SEM is not challenged by non-normal data, and it can produce robust observations with smaller datasets (Jr. et al., 2017; Sarstedt et al., 2016; Dey et al., 2020; Rai et al., 2013; Hung et al., 2021)

\section{RESULTS}

1. Reliability Analysis, Convergent and Discriminant Validity

The academic community has used PLS to investigate psychometric attributes of social processes like the interaction of individuals to change in their environment (Ashill et al., 2005); A key parameter of the measurement model's robustness is the construct reliability which is identified through the Cronbach's alpha coefficient. In this study, Cronbach's alpha value reach the accepted value of $\geq 0.5$, satisfying the criteria of construct reliability (Bagozzi and Yi, 1988) (Table 3). In Table 4, two vital criteria, the Composite Reliability (CR), which is a testament to the robustness of the indicators to the respective manifest variable is at an acceptable level of $\geq 0.7$, and the convergent validity or AVE (Average Value Extracted), a critical informatic to gauge variance due to measurement error is observed to be $>0.5$ which is admissible according to (Farrell, 2010). Through the Fornell-Lacker Criterion and the cross-loadings (Table 3), the discriminant validity of constructs is satisfied as square root of each construct's AVE is higher than its correlation with another construct, and each item loads highest with respect to its associated construct (Henseler et al., 2014).
Table 3. Fornell-Lacker Criterion

(Source: Authors' processing from SMART PLS 3.2.9)

\begin{tabular}{|c|c|c|c|c|c|}
\hline Variable & Items & Factor Loadings $(\lambda)$ & Cronbach's $\alpha$ & $\mathrm{CR}$ & AVE \\
\hline Place Image & $\begin{array}{l}\text { PLC1 } \\
\text { PLC2 } \\
\text { PLC3 } \\
\text { PLC4 }\end{array}$ & $\begin{array}{l}0.733 \\
0.801 \\
0.830 \\
0.674 \\
\end{array}$ & 0.765 & 0.846 & 0.581 \\
\hline $\begin{array}{l}\text { Safety and } \\
\text { Security }\end{array}$ & $\begin{array}{l}\text { SAF1 } \\
\text { SAF2 } \\
\text { SAF3 } \\
\text { SAF4 } \\
\end{array}$ & $\begin{array}{l}0.781 \\
0.868 \\
0.601 \\
0.697 \\
\end{array}$ & 0.734 & 0.849 & 0.653 \\
\hline $\begin{array}{l}\text { Resident's } \\
\text { Utilisation of } \\
\text { Tourism } \\
\text { Resources } \\
\end{array}$ & $\begin{array}{l}\text { RES1 } \\
\text { RES2 } \\
\text { RES3 }\end{array}$ & $\begin{array}{l}0.789 \\
0.868 \\
0.837\end{array}$ & 0.777 & 0.871 & 0.692 \\
\hline Well Being & $\begin{array}{l}\text { WEL1 } \\
\text { WEL2 } \\
\text { WEL3 }\end{array}$ & $\begin{array}{l}0.814 \\
0.836 \\
0.773\end{array}$ & 0.846 & 0.896 & 0.683 \\
\hline $\begin{array}{l}\text { Quality of } \\
\text { life }\end{array}$ & $\begin{array}{l}\text { QOL1 } \\
\text { QOL2 } \\
\text { QOL3 } \\
\text { QOL4 }\end{array}$ & $\begin{array}{l}0.804 \\
0.842 \\
0.873 \\
0.783 \\
\end{array}$ & 0.734 & 0.829 & 0.553 \\
\hline $\begin{array}{l}\text { Resident's } \\
\text { Perception }\end{array}$ & $\begin{array}{l}\text { REP1 } \\
\text { REP2 } \\
\text { REP3 }\end{array}$ & $\begin{array}{l}0.843 \\
0.847 \\
0.848\end{array}$ & 0.809 & 0.883 & 0.715 \\
\hline $\begin{array}{l}\text { Support for } \\
\text { Conservation }\end{array}$ & $\begin{array}{l}\text { SUC1 } \\
\text { SUC2 } \\
\text { SUC3 } \\
\text { SUC4 } \\
\end{array}$ & $\begin{array}{l}0.661 \\
0.785 \\
0.780 \\
0.741 \\
\end{array}$ & 0.751 & 0.833 & 0.503 \\
\hline
\end{tabular}

\section{Model Performance}

Table 4. Factor Reliability and Validity (Source: Author's Process from SMART PLS 3.2.9)

\begin{tabular}{|l|c|c|c|c|c|c|c|}
\hline \multicolumn{1}{|c|}{ Construct } & PLC_IMG & QUA_LIF & RES_PER_ & RES_UTI & SAF_SEC & SUP_CON & WELL_BEI \\
\hline PLC_IMG & $\mathbf{0 . 7 6 2}$ & & & & & & \\
\hline QUA_LIF & 0.374 & $\mathbf{0 . 7 4 4}$ & & & & & \\
\hline RES_PER & 0.116 & 0.299 & $\mathbf{0 . 8 4 6}$ & & & & \\
\hline RES_UTI & 0.373 & 0.278 & 0.167 & $\mathbf{0 . 8 3 2}$ & & & \\
\hline SAF_SEC & 0.409 & 0.448 & 0.041 & 0.462 & $\mathbf{0 . 8 0 8}$ & & \\
\hline SUPP_CON & 0.278 & 0.49 & 0.288 & 0.232 & 0.443 & $\mathbf{0 . 7 0 9}$ & \\
\hline WELL_BEI & -0.009 & 0.058 & 0.608 & -0.008 & -0.115 & 0.211 & $\mathbf{0 . 8 2 6}$ \\
\hline
\end{tabular}

Table. 5 Model Performance (Source: Authors' processing from SMART PLS 3.2.9)

\begin{tabular}{|c|c|c|c|c|c|c|c|}
\hline \begin{tabular}{|c|}
$\begin{array}{c}\text { Interaction } \\
\text { Type }\end{array}$ \\
\end{tabular} & Interactions & $\begin{array}{l}\text { Path Coeff. } \\
(\beta)\end{array}$ & $\begin{array}{c}\text { Sample } \\
\text { Mean (M) } \\
\end{array}$ & $\begin{array}{c}\text { Standard Deviation } \\
\text { (STDEV) }\end{array}$ & $\begin{array}{c}\text { T Statistics } \\
(|\mathrm{O} / \mathrm{STDEV}|) \\
\end{array}$ & P Values & $\begin{array}{c}\text { Hypothesis } \\
\text { Supported }\end{array}$ \\
\hline \multirow{4}{*}{ Moderation } & PLC_IMG*RES_PER -> SUP_CON & 0.08 & 0.08 & 0.06 & 1.337 & 0.18 & No \\
\hline & QUA_LIF*RES_PER -> SUP_CON & -0.012 & -0.012 & 0.052 & 0.221 & 0.82 & No \\
\hline & RES_UTI*RES_PER -> SUP_CON & 0.128 & 0.118 & 0.156 & 2.292 & 0.03 & Yes \\
\hline & SAF_SEC*RES_PER -> SUP_CON & -0.069 & -0.071 & 0.052 & 1.335 & 0.18 & No \\
\hline \multirow{5}{*}{ Direct } & PLC_IMG -> SUP_CON & 0.059 & 0.062 & 0.042 & 1.403 & 0.16 & No \\
\hline & QUA_LIF -> SUP_CON & 0.331 & 0.334 & 0.044 & 7.439 & 0.00 & Yes \\
\hline & RES_UTI -> SUP_CON & -0.089 & -0.083 & 0.054 & 1.656 & 0.09 & No \\
\hline & SAF_SEC -> SUP_CON & 0.321 & 0.316 & 0.053 & 6.073 & 0.00 & Yes \\
\hline & WELL_BEI -> SUP_CON & 0.191 & 0.191 & 0.052 & 3.643 & 0.00 & Yes \\
\hline & $\begin{array}{l}\text { Dependent Variable: } \\
\text { SUP_CON }\end{array}$ & \multicolumn{4}{|c|}{$\begin{array}{c}\text { Coefficient of Determination }\left(\mathrm{R}^{2}\right) \text { : } \\
0.381(38 \%)\end{array}$} & \multicolumn{2}{|c|}{$\begin{array}{l}\text { Empirical Remark: Satisfac- } \\
\text { tory (significant at } \mathrm{p}<0.05 \text { ) }\end{array}$} \\
\hline
\end{tabular}




\section{DISCUSSIONS}

The study considers 4 moderating interactions and 5 direct interactions, thereby giving rise to 9 testable assumptions. The opening part of this segment shall discuss the assumptions concerning direct relationships among the dependent and independent variables. The next part shall cover the discourse on the moderating terms in determining the dependent variable. The first hypothetical assumption hypothesises the efficacy of place images in predicting support for conservation. In the extant literature, it is observed that this particular association is positive (place image and support for heritage conservation) according to (Stylidis et al., 2016). As an alternative antecedent to a case study on the effect of place branding on landscape conservation in Switzerland, authors (Tobias and Müller Wahl, 2013) observe a similar positive affinity between the notion of place image and support for landscape conservation.

In this particular study among the old city residents, Jodhpur, the authors have detected a negative correspondence among place image and support for conservation, which signifies a potent departure from earlier studies (Table 5). Extant studies that have been built on the Social Exchange Theory (SET) like (Ap, 1992; Gursoy and Rutherford, 2004; Stylidis et al., 2014b) have observed that constructs like place attachment and image have been found negative in predicting conservation support. These findings corroborate the findings of this study.

The second hypothetical statement deals with testing the correlation between safety and security and support for geoheritage conservation. In conjunction with studies that centre around similar themes, authors (Pegas et al., 2013) observed that when it comes to the conservation of marine heritage, residents of a particular Brazilian village emit positive emotional response given the fact that conservation efforts may impact the villagers' safe passage to the coastal ridge. This antecedent has signalled similarity with the findings of our study wherein the assumption of a positive correlation between safety and security of residents and support for conservation has been accepted (Table 5). In their research (Priporas et al., 2017) test the effect of community sense of safety and security on conservation behaviour among AirBnB users. The study was underpinned by the Social Exchange Theory (SET) and exhibited a positive correlation between safety and security and conservation proclivity. The current research records a positive association between safety and security and support for geoheritage conservation in alignment with the SET's previous finding.

Thirdly, a hypothesis was developed to test the relationship between residents' utilisation of tourism resources and support for geoheritage conservation. It was observed in this study that there exists a negative correlation between the two constructs. It is noteworthy that previous researches in the field like (Jurowski et al., 1997c), have outlined a significant positive relationship among residents using resources meant for tourists.

Their support for the conservation of tangible heritage (Nunkoo and Ramkissoon, 2010) adds to the discourse by studying residents' support towards developing an integrated resort in Mauritius. Their study indicates a positive linear relationship among the variables in question. In our study, the relationship between the residents' utilisation of tourism resources and support for geoheritage conservation in the context of residents of the old city, Jodhpur, is negative, which again is a departure from the conventional findings (Table 5). A plausible explanation may be the implication of Weber's two-factor rationalisation because respondents who are primarily dwellers of the area around the geoheritage do not sense a positive outcome from the tourism activities and the subsequent conservation efforts. Boley et al., 2014 argue that the locals may become distant from any development program in their community if the benefits are not perceivable. It is here that authors like (Gannon et al., 2021) have deployed Weber's two-factor rationalisation theory in addition to the SET to understand the relationship between residents' utilisation of tourism resources and support for geoheritage conservation, as the former theoretical underlining captures psycho-cognitive states beyond the emotionbased confines traditionally offered by the SET (Mody and Day, 2014).

The fourth assumption of interest is a probable positive link between resident's well-being and support for geoheritage conservation. In a parallel investigation, (Chen et al., 2020) studied the construct of well-being due to the interaction between tourists and residents. Park et al., 2017 have identified a positive association between tourism development and community well-being which is mirrored by findings (Gannon et al., 2020). In our study, empirical evidence suggests that resident's well-being plays a significant and positive part in assessing the support for geoheritage conservation in the old city of Jodhpur (Table 5). The association between resident's well being and support for conservation has underpinnings from Weber's two-factor rationality and SET (Yolal et al., 2016), wherein a positive link has been ascertained between the tested factors. This is in conjunction with the findings of this investigation.

The fifth hypothesis dealt with investigating the direct relationship between quality of life and support for geoheritage conservation. In conjunction with studies like (Liang and Hui, 2016b) who have found a positive correlation between the quality of life and support for tourism development. Because support for conservation of geoheritage as a context hasn't been studied before, our result of a positive relationship among the constructs in question is a novel finding. Our study is further strengthened by the empirical findings by (Yu et al., 2011), who observe strong affiliation of the quality of life construct in impacting residents' support to tourism development, which we consider a proxy to support geo-heritage conservation (Table 5). Quality of life construct has robust foundations from the SET (Liang and Hui, 2016b), which has been tested in contexts concerning support for tourism development and not conservation of any heritage site, which may be considered an addition to the existing corpus of knowledge.

This study introduces 4 investigative assumptions to gauge the moderating efficiency of residents' perception to predict support for geoheritage conservation. While 3 assumptions were found to lack empirical evidence to be accepted, the one moderating interaction having residents' utilisation of tourism resources as a pathway to the dependent variable (Residents' utilisation of tourism resources* Resident's perception-> support for conservation) has been identified as a robust moderating effect. Incidentally, there are no antecedents in extant literature to derive for this special relationship. 
A scoping literature review from leading scientific directories like Scopus and Web of Science leads us to describe the findings of the interaction terms mentioned above as being novel.

\section{Expected contribution to theory and practice}

The theoretical contribution of this study is that the Weber's 2 Factor Rationality is deployed with the behavioural aspects of the Social Exchange Theory (SET) to scrutinise the behaviour of residents towards geoheritage conservation and tourism development in their locality. This gives another dimension for academicians to approach issues related to the conflict between residents needs and tourists wants, thereby augmenting and extending the spectrum of the Social Exchange Theory. After a thorough systematic literature review and practising abundant caution, it can be discerned that the study's novelty includes the inculcation of constructs like residents' quality of life and well-being to study the factors of support for conservation and tourism development (Gannon et al., 2020). Progressively, the moderating interactions significantly affects the predictive capacity of the theoretical framework used in this study.

The practical aspect of the study is immense. It gives the practitioners leverage to better plan for managing geoheritage sites and develop robust strategies for their development, keeping in mind the duplicity of resources. By deploying novel attributes like residents' quality of life and the moderating effect of resident's perception to model conservation support behaviour among the local community, the sustainability of the delicate geoheritage site. Our study contains a postpositivist approach which implies that support for geoheritage conservation includes a critical element of human context that makes the role of residents a vital component of planning or executing geoheritage conservation endeavours. It is interesting to note that the Mehrangarh fort was featured in the critically acclaimed Hollywood film 'The Dark Night Rises" (Nolan, 2012), in addition to the numerous Hindi language movies filmed in and around the vicinity of the fort and the igneous rock structures. These developments have made the promotion and conservation of the geoheritage site the need of the hour. Policies should provide impetus to evolving touristic activities like film tourism, rock tourism and heritage tourism.

Future researches should focus on increasing the generalizability of the study by conducting longitudinal studies. The authors recommend the time-lag method of data collection wherein the responses are more robust, and measurement biasrelated issues are also reduced significantly (Ali et al., 2020). Furthermore, future investigations could employ constructs that manifest non-hedonic, non-volitional and self-reflective attributes of residents' behaviour towards geoheritage conservation and tourism development, especially in middle-income countries like India (Verma and Chandra, 2018)

\section{Acknowledgement}

The investigation has been supported by Tomas Bata University in Zlin, Internal Grant Agency Fund No. IGA/FaME/2020/005.

\section{REFERENCES}

Ajayi, O.O., \& Tichaawa, T.M. (2020). Visitors" Characteristics and Destination Image: The Case of Nigerian Zoos. GeoJournal of Tourism and Geosites, 32(4), 1410-1417. https://doi.org/10.30892/gtg.32432-588

Ali, M., Usman, M., Pham, N.T., Agyemang-Mintah, P., \& Akhtar, N. (2020). Being ignored at work: Understanding how and when spiritual leadership curbs workplace ostracism in the hospitality industry. International Journal of Hospitality Management, 91, 102696. https://doi.org/10.1016/J.IJHM.2020.102696

Allen, L.R., Hafer, H.R., Long, P.T., \& Perdue, R.R. (1993). Rural residents' attitudes toward recreation and tourism development. Journal of Travel Research, 31(4), 27-33. https://doi.org/10.1177/004728759303100405

Andereck, K.L., \& Nyaupane, G.P. (2011). Exploring the Nature of Tourism and Quality of Life Perceptions among Residents. Journal of Travel Research, 50(3), 248-260. https://doi.org/10.1177/0047287510362918

Andereck, K.L., Valentine, K.M., Knopf, R.C., \& Vogt, C.A. (2005). Residents' perceptions of community tourism impacts. Annals of Tourism Research, 32(4), 1056-1076. https://doi.org/10.1016/j.annals.2005.03.001

Andereck, K.L., \& Vogt, C.A. (2000). The relationship between residents' attitudes toward tourism and tourism development options. Journal of Travel Research, 39(1), 27-36. https://doi.org/10.1177/004728750003900104

Anholt, S. (2010). Towards governmental social responsibility. In Place Branding and Public Diplomacy, 6(2), 69-75. https://doi.org/10.1057/pb.2010.18

Ap, J. (1992). Residents' perceptions on tourism impacts. Annals of Tourism Research, 19(4), 665-690. https://doi.org/10.1016/01607383(92) $90060-3$

Ashill, N.J., Carruthers, J., \& Krisjanous, J. (2005). Antecedents and outcomes of service recovery performance in a public health-care environment. Journal of Services Marketing, 19(5), 293-308. https://doi.org/10.1108/08876040510609916

Bagozzi, R.P., \& Yi,Y. (1988). On the evaluation of structural equation models. Journal of the Academy of Marketing Science, 16(1), 74-94. https://doi.org/10.1007/BF02723327

Blanford, W.T. (1877). Geological notes on the Great Indian Desert between Sind and Rajputana. Rec. of the Geological Survey of India. 10, 10-21.

Boğan, E., Dedeoğlu, B.B., \& Balikçioğlu Dedeoğlu, S. (2020). The effect of residents' perception of hotel social responsibility on overall attitude toward tourism. Tourism Review. https://doi.org/10.1108/TR-08-2019-0353

Boisen, M., Terlouw, K., \& Van Gorp, B. (2011). The selective nature of place branding and the layering of spatial identities. Journal of Place Management and Development, 4(2), 135-147. https://doi.org/10.1108/17538331111153151

Boley, B.B., McGehee, N.G., Perdue, R.R., \& Long, P. (2014). Empowerment and resident attitudes toward tourism: Strengthening the theoretical foundation through a Weberian lens. Annals of Tourism Research, 49, 33-50. https://doi.org/10.1016/J.ANNALS.2014.08.005

Boley, B. Bynum \& McGehee, Nancy G. \& Perdue, Richard R. \& Long, Patrick, 2014. Empowerment and resident attitudes toward tourism: Strengthening the theoretical foundation through a Weberian lens. Annals of Tourism Research, Elsevier, 49(C), 33-50.

Burckhardt, C.S., \& Anderson, K.L. (2003). The Quality of Life Scale (QOLS): Reliability, validity, and utilization. In Health and Quality of Life Outcomes, 1, 60, BioMed Central. https://doi.org/10.1186/1477-7525-1-60 
Byrd, E.T., Bosley, H.E., \& Dronberger, M.G. (2009). Comparisons of stakeholder perceptions of tourism impacts in rural eastern North Carolina. Tourism Management, 30(5), 693-703. https://doi.org/10.1016/j.tourman.2008.10.021

Chen, Y., Cottam, E., \& Lin, Z. (2020). The effect of resident-tourist value co-creation on residents' well-being. Journal of Hospitality and Tourism Management, 44, 30-37. https://doi.org/10.1016/j.jhtm.2020.05.009

Chiciudean, G.O., Harun, R., Ilea, M., Chiciudean, D.I., Arion, F.H., Ilies, G., \& Muresan, I.C. (2019). Organic food consumers and purchase intention: A case study in Romania. Agronomy, 9(3), 145. https://doi.org/10.3390/agronomy9030145

COCHRANE, J., \& TAPPER, R. (2006). Tourism's contribution to World Heritage Site management. In Leask A \& Fyall A (Eds.), Managing World Heritage Sites, 97-109. Elsevier. https://doi.org/10.1016/b978-0-7506-6546-9.50017-4

Coulson, A. (1933). The geology of Sirohi state, Rajputana. Rec of Geological Survey of India. 63(1), 166.

Cropanzano, R., Anthony, E.L., Daniels, S.R., \& Hall, A.V. (2017). Social exchange theory: A critical review with theoretical remedies. Academy of Management Annals, 11(1), 479-516. https://doi.org/10.5465/ANNALS.2015.0099

Da Silva Lopes, H., Remoaldo, P., \& Ribeiro, V. (2019). Residents' perceptions of tourism activity in a rural North-Eastern Portuguese community: A cluster analysis. Bulletin of Geography. Socio-Economic Series, 46(46), 119-135. https://doi.org/10.2478/bog-2019-0038

Davis, D., Allen, J., \& Cosenza, R. (1988). Segmenting local residents by their attitudes, interests, and opinions toward tourism. Journals.Sagepub.Com. https://journals.sagepub.com/doi/abs/10.1177/004728758802700201

Deery, M., Jago, L., \& Fredline, L. (2012). Rethinking social impacts of tourism research: A new research agenda. Tourism Management, 33(1), 64-73. https://doi.org/10.1016/j.tourman.2011.01.026

Dey, S.K., Khan, K.A., Tuckova, Z., \& Jibril, A.B. (2020). Motivation among travel agents in India: The moderating role of employee's expertise and marital status. Problems and Perspectives in Management, 18(2), 453-465. https://doi.org/10.21511/PPM.18(2).2020.37

Dinnie, K. (2011). Introduction to the Theory of City Branding. In City Branding, 3-7. Palgrave Macmillan UK. https://doi.org/10.1057/9780230294790_1

Drumm, A., \& Bank, W. (2005). Ecotourism Development-A Manual for Conservation Planners and Managers. An Introduction to Ecotourism Planning, Volume I. https://www.researchgate.net/publication/277786951

Farrell, A.M. (2010). Insufficient discriminant validity: $\{$ A $\}$ comment on $\{$ Bove $\}$, \{Pervan $\}$, $\{$ Beatty $\}$, and $\{$ Shiu $\}$ (2009). Journal of Business Research, 63(3), 324-327. https://doi.org/10.1016/j.jbusres.2009.05.003

Gannon, M., Rasoolimanesh, S.M., \& Taheri, B. (2020). Assessing the Mediating Role of Residents' Perceptions toward Tourism Development. Journal of Travel Research, 004728751989092. https://doi.org/10.1177/0047287519890926

Gannon, M., Rasoolimanesh, S.M., \& Taheri, B. (2021). Assessing the Mediating Role of Residents' Perceptions toward Tourism Development. Journal of Travel Research, 60(1), 149-171. https://doi.org/10.1177/0047287519890926

Garau-Vadell, J.B., Díaz-Armas, R., \& Gutierrez-Taño, D. (2013). Residents' Perceptions of Tourism Impacts on Island Destinations: A Comparative Analysis. Wiley Online Library, 16(6), 578-585. https://doi.org/10.1002/jtr.1951

García, F., Vázquez, A., \& Macías, R. (1995). Resident's attitudes towards the impacts of tourism. Tourism Management Perspectives, 13, 33-40. https://doi.org/10.1016/j.tmp.2014.11.002

Gursoy, D., Jurowski, C., \& Uysal, M. (2002). Resident attitudes: A structural modeling approach. Annals of Tourism Research, 29(1), 79-105. https://doi.org/10.1016/S0160-7383(01)00028-7

Gursoy, D., \& Rutherford, D.G. (2004). Host attitudes toward tourism: An improved structural model. Annals of Tourism Research, 31(3), 495-516. https://doi.org/10.1016/j.annals.2003.08.008

Hair, J., Hollingsworth, C.L., Randolph, A.B., \& Chong, A.Y.L. (2017). An updated and expanded assessment of $\{$ PLS $\}-\{$ SEM $\}$ in information systems research. Industrial Management and Data Systems, 117(3), 442-458. https://doi.org/10.1108/IMDS-04-2016-0130

Han, H., Eom, T., Chung, H., Lee, S., Ryu, H.B., \& Kim, W. (2019). Passenger Repurchase Behaviours in the Green Cruise Line Context: Exploring the Role of Quality, Image, and Physical Environment. Sustainability, 11(7). https://doi.org/10.3390/su11071985

Hankinson, G. (2004). The brand images of tourism destinations: A study of the saliency of organic images. Journal of Product \& Brand Management, 13(1), 6-14. https://doi.org/10.1108/10610420410523803

Henderson, K.A. (2011). Post-positivism and the pragmatics of leisure research. Leisure Sciences, 33(4), 341-346. https://doi.org/10.1080/01490400.2011.583166

Henseler, J., Ringle, C.M., \& Sarstedt, M. (2014). A new criterion for assessing discriminant validity in variance-based structural equation modeling. Journal of the Academy of Marketing Science, 43(1), 115-135. https://doi.org/10.1007/s11747-014-0403-8

Hung, V.V., Dey, S.K., Vaculcikova, Z., \& Anh, L.T.H. (2021). The Influence of Tourists' Experience on Destination Loyalty: A Case Study of Hue City, Vietnam. Sustainability, 13(16), 8889. https://doi.org/10.3390/SU13168889

Hwang, D., Stewart, W.P., \& Ko, D. (2012). Community Behavior and Sustainable Rural Tourism Development. Journal of Travel Research, 51(3), 328-341. https://doi.org/10.1177/0047287511410350

Imbeah, N., Khademi-Vidra, A., \& Bujdoso, Z. (2020). Assessment of Tourists' Perceptions on Safety at the Cape Coast Tourist Destination in Ghana. GeoJournal of Tourism and Geosites, 28(1), 217. https://doi.org/10.30892/gtg.28117-464

Jaafar, M., Noor, S.M., \& Rasoolimanesh, S.M. (2015). Perception of young local residents toward sustainable conservation programmes: A case study of the Lenggong World Cultural Heritage Site. Tourism Management, 48, 154-163. https://doi.org/10.1016/j.tourman.2014.10.018

Jr., J.F.H., Matthews, L.M., Matthews, R.L., \& Sarstedt, M. (2017). PLS-SEM or CB-SEM: updated guidelines on which method to use. International Journal of Multivariate Data Analysis, 1(2), 107. https://doi.org/10.1504/ijmda.2017.087624

Jurowski, C., \& Gursoy, D. (2004). Distance effects on residents' attitudes toward tourism. Annals of Tourism Research, 31(2), $296-312$. https://doi.org/10.1016/j.annals.2003.12.005

Jurowski, C., Uysal, M., \& Williams, D.R. (1997a). A theoretical analysis of host community resident reactions to tourism. Journal of Travel Research, 36(2), 3-11. https://doi.org/10.1177/004728759703600202

Jurowski, C., Uysal, M., \& Williams, D.R. (1997b). A Theoretical Analysis of Host Community Resident Reactions to Tourism. Journal of Travel Research, 36(2), 3-11. https://doi.org/10.1177/004728759703600202

Jurowski, C., Uysal, M., \& Williams, D.R. (1997c). A Theoretical Analysis of Host Community Resident Reactions to Tourism. Journal of Travel Research, 36(2), 3-11. https://doi.org/10.1177/004728759703600202

Kaur, G., Ahuja, A., Thakur, S.N., Pandit, M., Duraiswami, R., Singh, A., Kaur, P., Saini, J., Goswami, R.G., Prakash, J., Acharya, K., Singh, S., \& Garg, S. (2020). Jodhpur Sandstone: an Architectonic Heritage Stone from India. Geoheritage, 2020 12:1, $12(1)$, 1-17. 
https://doi.org/10.1007/S12371-020-00441-Y

Khayati, S., \& Zouaoui, S.K. (2013). Perceived Usefulness and Use of Information Technology: the Moderating Influences of the Dependence of a Subcontractor towards His Contractor. Journal of Knowledge Management, Economics and Information Technology, III. www.scientificpapers.org

Kim, Y.J., Njite, D., \& Hancer, M. (2013). Anticipated emotion in consumers' intentions to select eco-friendly restaurants: Augmenting the theory of planned behavior. International Journal of Hospitality Management, 34(1), 255-262. https://doi.org/10.1016/j.ijhm.2013.04.004

Ko, D.W., \& Stewart, W.P. (2002). A structural equation model of residents' attitudes for tourism development. Tourism Management, 23(5), 521-530. https://doi.org/10.1016/S0261-5177(02)00006-7

Konstantaki, M., \& Wickens, E. (2010). Residents' perceptions of environmental and security issues at the 2012 London Olympic Games. Journal of Sport and Tourism, 15(4), 337-357. https://doi.org/10.1080/14775085.2010.533921

Kotler, P., Haider, D., \& Rein, I. (1993). There's no place like our place! The marketing of cities, regions, and nations. The Futurist, 14. https://doi.org/10.1016/S0550-3213(01)00405-8

La Touche, T.H.D. (1902). Geology of western Rajputana. In Memoirs of the Geological survey of India. Rec. of The Geological survey. 35(1).

Lama, S., \& Rathore, S.S. (2018). Crime Mapping and Crime Analysis of Property Crimes in Jodhpur. International Annals of Criminology, 55(2). https://doi.org/10.1017/cri.2017.11

Látková, P., \& Vogt, C.A. (2012). Residents' Attitudes toward Existing and Future Tourism Development in Rural Communities On behalf of: Travel and Tourism Research Association can be found at: Journal of Travel Research Additional services and information for Residents' Attitudes toward Existing and Future Tourism Development in Rural Communities. Journal of Travel Research Downloaded from Journal of Travel Research, 51(1), 50-67. https://doi.org/10.1177/0047287510394193

Liang, Z.X., \& Hui, T.K. (2016a). Residents' quality of life and attitudes toward tourism development in China. Tourism Management, 57, 56-67. https://doi.org/10.1016/J.TOURMAN.2016.05.001

Liang, Z.X., \& Hui, T.K. (2016b). Residents' quality of life and attitudes toward tourism development in China. Tourism Management, 57, 56-67. https://doi.org/10.1016/j.tourman.2016.05.001

Lopes, H.D.S., Remoaldo, P., \& Ribeiro, V. (2019). Residents' perceptions of tourism activity in a rural North-Eastern Portuguese community: a cluster analysis. Bulletin of Geography. Socio-Economic Series, 46(46), 119-135. https://doi.org/10.2478/bog-2019-0038

Lopes, H.S., Ribeiro, V., \& Remoaldo, P.C. (2019). Spatial Accessibility and Social Inclusion: The Impact of Portugal's Last Health Reform. GeoHealth, 3(11), 356-368. https://doi.org/10.1029/2018GH000165

Manwa, H. (2003). Wildlife-based Tourism, Ecology and Sustainability: A tug-of-war among competing interests in Zimbabwe. Journal of Tourism Studies, 14(2), 45-54. https://doi.org/10.3316/ielapa.200402853

Maps, G.M. (2012). Mehrangarh Fort Area, Jodhpur City, India. Google Maps. https://www.google.com/maps/d/u/0/edit?mid= 1ROOjisXSeoqJdpq7wVH6ikYM_8Y\&ie=UTF8\&oe=UTF8\&msa=0\&ll=26.30114892032734\%2C73.01697093846143\&z=15

Megeirhi, H.A., Woosnam, K.M., Ribeiro, M.A., Ramkissoone, H.R., \& Denley, T.J. (2020). Employing a value-belief-norm framework to gauge Carthage residents' intentions to support sustainable cultural heritage tourism. Journal of Sustainable Tourism. https://doi.org/10.1080/09669582.2020.1738444

Mody, M., \& Day, J. (2014). Rationality of social entrepreneurs in tourism: Max Weber and the sociology of tourism development. International Journal of Tourism Anthropology, 3(3), 227. https://doi.org/10.1504/IJTA.2014.059839

Monterrubio, C., Andriotis, K., \& Rodríguez-Muñoz, G. (2020). Residents’ perceptions of airport construction impacts: A negativity bias approach. Tourism Management, 77. https://doi.org/10.1016/j.tourman.2019.103983

Muresan, I.C., Harun, R., Arion, F.H., Oroian, C.F., Dumitras, D.E., Mihai, V.C., Ilea, M., Chiciudean, D.I., Gliga, I.D., \& Chiciudean, G.O. (2019). Residents' perception of destination quality: Key factors for sustainable rural development. Sustainability (Switzerland), 11(9). https://doi.org/10.3390/su11092594

Ng, S.L., \& Feng, X. (2020). Residents' sense of place, involvement, attitude, and support for tourism: a case study of Daming Palace, a Cultural World Heritage Site. Asian Geographer. https://doi.org/10.1080/10225706.2020.1729212

Nicholas, L., Thapa, B., \& Ko, Y. (2009). Residents'perspectives of a world heritage site: The pitons management area, st. Lucia. Annals of Tourism Research, 36(3), 390-412. https://doi.org/10.1016/j.annals.2009.03.005

Nolan, C. (2012). The Dark Knight rises (p. 415). Warner Bros. Pictures.

Nunkoo, R., \& Ramkissoon, H. (2010). Modeling community support for a proposed integrated resort project. Journal of Sustainable Tourism, 18(2), 257-277. https://doi.org/10.1080/09669580903290991

Pandey, D.K., \& Bahadur, T. (2009). A review of the stratigraphy of Marwar Supergroup of west-central Rajasthan. Journal of the Geological Society of India, 73(6), 747-758. https://doi.org/10.1007/S12594-009-0060-6

Pareek, H.S. (1981). Petrochemistry and Petrogenesis of the Malani Igneous Suite, India. GSA Bulletin, 92(2_Part_II), 206-273. https://doi.org/10.1130/GSAB-P2-92-206

Park, K., Lee, J., \& Lee, T.J. (2017). Residents' attitudes toward future tourism development in terms of community well-being and attachment. Asia Pacific Journal of Tourism Research, 22(2), 160-172. https://doi.org/10.1080/10941665.2016.1208669

Park, S., Zielinski, S., Jeong, Y., \& Kim, S. (2020). Factors Affecting Residents' Support for Protected Area Designation. Sustainability, 2020, 12(7), 2800. https://doi.org/10.3390/SU12072800

Pascoe, E.H. (1959). Manual of Geology of India and Burma. Government of India Press, Calcutta, 2, 484-1338

Pegas, F.D.V., Coghlan, A., Stronza, A., \& Rocha, V. (2013). For love or for money? Investigating the impact of an ecotourism programme on local residents' assigned values towards sea turtles. Journal of Ecotourism, 12(2), 90-106. https://doi.org/10.1080/14724049.2013.831099

Priporas, C.V., Stylos, N., Vedanthachari, L.N., \& Santiwatana, P. (2017). Service quality, satisfaction, and customer loyalty in \{Airbnb\} accommodation in \{Thailand\}. International Journal of Tourism Research, 19(6), 693-704. https://doi.org/10.1002/jtr.2141

Rai, A., Goodhue, D.L., Henseler, J., \& Thompson, R. (2013). To PLS or Not to PLS: That is the Question. AMCIS 2013 Proceedings. https://aisel.aisnet.org/amcis2013/Panels/PanelSubmissions/2

Ranasinghe, R., \& Pradeepamali, J. (2019). Community Empowerment and their Support for Tourism Development: an Inquiry based on Resident Empowerment through Tourism Scale. Journal of Tourism and Services, 10(19), 55-76. https://doi.org/10.29036/JOTS.V10I19.96

Rasoolimanesh, S.M., Jaafar, M., \& Barghi, R. (2017). Effects of Motivation, Knowledge and Perceived Power on Residents' Perceptions: Application of Weber's Theory in World Heritage Site Destinations. International Journal of Tourism Research, 19(1), 68-79. https://doi.org/10.1002/JTR.2085

Rasoolimanesh, S.M., Jaafar, M., Kock, N., \& Ahmad, A.G. (2017). The effects of community factors on residents' perceptions toward 
World Heritage Site inscription and sustainable tourism development. Journal of Sustainable Tourism, 25(2), 198-216. https://doi.org/10.1080/09669582.2016.1195836

Rasoolimanesh, S.M., Jaafar, M., Kock, N., \& Ramayah, T. (2015). A revised framework of social exchange theory to investigate the factors influencing residents' perceptions. Tourism Management Perspectives, 16, 335-345. https://doi.org/10.1016/j.tmp.2015.10.001

Rasoolimanesh, S.M., Md Noor, S., Schuberth, F., \& Jaafar, M. (2019). Investigating the effects of tourist engagement on satisfaction and loyalty. The Service Industries Journal, 39(7-8), 559-574. https://doi.org/10.1080/02642069.2019.1570152

Rasoolimanesh, S.M., Roldán, J.L., Jaafar, M., \& Ramayah, T. (2017). Factors Influencing Residents' Perceptions toward Tourism Development: Differences across Rural and Urban World Heritage Sites. Journal of Travel Research, 56(6), 760-775. https://doi.org/10.1177/0047287516662354

Rasoolimanesh, S.M., \& Seyfi, S. (2020). Residents' perceptions and attitudes towards tourism development: a perspective article. Tourism Review, 76(1), 51-57. https://doi.org/10.1108/TR-11-2019-0461

Sarstedt, M., Hair, J.F., Ringle, C.M., Thiele, K.O., \& Gudergan, S.P. (2016). Estimation issues with PLS and CBSEM: Where the bias lies! Journal of Business Research, 69(10), 3998-4010. https://doi.org/10.1016/j.jbusres.2016.06.007

Sarstedt, M., Ringle, C.M., \& Hair, J.F. (2014). PLS-SEM: Looking Back and Moving Forward. In Long Range Planning, 47(3), 132137, Elsevier Ltd. https://doi.org/10.1016/j.lrp.2014.02.008

Sharpley, R. (2014). Tourism: A vehicle for development? In Tourism and Development: Concepts and Issues, 2nd Edition, 3-30, Channel View Publications. https://doi.org/10.21832/9781845414740-003

Shields, R. (2013). Places on the margin: Alternative geographies of modernity. Routledge.

Stachow, G., \& Hart, C. (2010). Exploring place image: Formation and measurement. Place Branding and Public Diplomacy, 6(2), 145155. https://doi.org/10.1057/pb.2010.13

Stylidis, D., Biran, A., Sit, J., \& Szivas, E.M. (2014a). Residents' support for tourism development: The role of residents' place image and perceived tourism impacts. Tourism Management, 45, 260-274. https://doi.org/10.1016/J.TOURMAN.2014.05.006

Stylidis, D., Biran, A., Sit, J., \& Szivas, E.M. (2014b). Residents' support for tourism development: The role of residents' place image and perceived tourism impacts. Tourism Management, 45, 260-274. https://doi.org/10.1016/j.tourman.2014.05.006

Stylidis, D., Sit, J., \& Biran, A. (2016). An Exploratory Study of Residents' Perception of Place Image: The Case of Kavala. Retrieved June 13, 2021, from https://journals.sagepub.com/doi/pdf/10.1177/0047287514563163

Su, L., Swanson, S.R., \& He, X. (2019). A scale to measure residents perceptions of destination social responsibility. Journal of Sustainable Tourism, 1-25. https://doi.org/10.1080/09669582.2019.1708372

Syarafina Mohd Fauzi, N., \& Misni, A. (2016). Geoheritage Conservation: Indicators affecting the condition and sustainability of Geopark - a conceptual review. Procedia-Social and Behavioral Sciences, 222, 676-684. https://doi.org/10.1016/j.sbspro.2016.05.224

Tobias, S., \& Müller Wahl, P. (2013). Can place branding support landscape conservation in city-regions? A case study from Switzerland. Land Use Policy, 30(1), 266-275. https://doi.org/10.1016/j.landusepol.2012.03.021

Uysal, M., Sirgy, M.J., Woo, E., \& Kim, H.L. (2016). Quality of life (QOL) and well-being research in tourism. In Tourism Management, 53, 244-261, Elsevier Ltd. https://doi.org/10.1016/j.tourman.2015.07.013

Verma, V.K., \& Chandra, B. (2018). An application of theory of planned behavior to predict young Indian consumers' green hotel visit intention. Journal of Cleaner Production, 172, 1152-1162. https://doi.org/10.1016/j.jclepro.2017.10.047

Wang, S., Bickle, M., \& Harrill, R. (2010). Residents' attitudes toward tourism development in Shandong, China. International Journal of Culture, Tourism and Hospitality Research, 4(4), 327-339. https://doi.org/10.1108/17506181011081505

Wang, Y \& Pfister, R.E. (2008). Residents' Attitudes Toward Tourism and Perceived Personal Benefits in a Rural Community. Journal of Travel Research, 47(1), 84-93. https://doi.org/10.1177/0047287507312402

Ward, C., \& Berno, T. (2011). Beyond social exchange theory. Attitudes toward tourists. Annals of Tourism Research, 38(4), 1556-1569. https://doi.org/10.1016/j.annals.2011.02.005

Warnaby, G. (2009). Towards a service-dominant place marketing logic. Marketing Theory, 9(4), 403-423. https://doi.org/10.1177/1470593109346898

Weber, M. (1978). Economy and Society. An Outline of Interpretative Sociology. In University of California Press.

Williams, J., \& Lawson, R. (2001). Community issues and resident opinions of tourism. Annals of Tourism Research, 28(2), 269-290. https://doi.org/10.1016/S0160-7383(00)00030-X

Wu, D., Shen, C., Wang, E., Hou, Y., \& Yang, J. (2019). Impact of the perceived authenticity of heritage sites on subjectivewell-being: A study of the mediating role of place attachment and satisfaction. Sustainability (Switzerland), 11(21), 6148. https://doi.org/10.3390/su11216148

Yolal, M., Gursoy, D., Uysal, M., Kim, H. \& Karacaoğlu, S. (2016). Impacts of festivals and events on residents' well-being. Annals of Tourism Research, 61, 1-18. https://doi.org/10.1016/J.ANNALS.2016.07.008

Yu, C.P, Chancellor, H. C., \& Shu Tian Cole. (2011). Measuring Residents' Attitudes toward Sustainable Tourism: A Reexamination of the Sustainable Tourism Attitude Scale. Journal of Travel Research, 50(1), 57-63. https://doi.org/10.1177/0047287509353189

Zheng, D., Ritchie, B.W., \& Benckendorff, P.J. (2020). Beyond cost-benefit analysis: resident emotions, appraisals and support toward tourism performing arts developments. Current Issues in Tourism, 1-17. https://doi.org/10.1080/13683500.2020.1732881

Zheng, D., Ritchie, B.W., Benckendorff, P.J., \& Bao, J. (2019). The role of cognitive appraisal, emotion and commitment in affecting resident support toward tourism performing arts development. Journal of Sustainable Tourism, 27(11), 1725-1744. https://doi.org/10.1080/09669582.2019.1662029

Article history: Received: 28.05.2021 Revised: 22.08.2021 Accepted: 23.09.2021 Available online: 18.10.2021 